\title{
PRIORITY MODERN AND PROMISING AREAS OF THE PROFESSIONAL ACTIVITY OF A CLINICAL PHARMACIST AT DIFFERENT STAGES OF DEVELOPMENT OF CLINICAL PHARMACY IN UKRAINE
}

\author{
T.B.Ryvak, A.B.Zimenkovsky, Kh.I.Makukh
}

Danylo Halytsky Lviv National Medical University

Key words: clinical pharmacy; pharmaceutical care; professional activity of a clinical pharmacist

\begin{abstract}
Clinical pharmacy now is at the stage of intensive development, its key points gradually being implemented in practical healthcare in Ukraine. The regulatory support of the activity of a clinical pharmacist, methodological aspects, as well as definition of his/her role and place in different areas of the national healthcare are important and necessary for the successful implementation of this process. A comparative study of the existing and promising directions of the clinical pharmacist's professional activity at different stages of the clinical pharmacy development has been conducted. According to the results of the study conducted three main modern blocks (15 directions) of the professional activity of a clinical pharmacist at the present stage of development of clinical pharmacy in Ukraine have been identified: I) information and terminology; II) methodological-didactic, III) expert and formulary. The block (4 directions) of the promising professional activity has been also determined, namely: creation of expert systems (mobile medical applications); analysis of cases on-line; participation in writing grant projects; search and development of new classification systems of clinical and pharmaceutical interventions. All directions of the clinical pharmacist activity can be combined in a new, in our opinion, two-vector concept - management of drug-related problems (DRPS) (identification, analysis, standardization, clinical and pharmaceutical intervention, pharmacoeconomic studies, etc.) and formation of the messages of pharmaceutical care (including assessment of its quality). However, we consider that according to the vectors of further development of clinical pharmacy the professional directions of the clinical pharmacist may vary.
\end{abstract}

In Ukraine, clinical pharma-

lcy (CP) is at the stage of rapid development, its key provisions are gradually being introduced in practical healthcare (HC). The regulatory support of the activity of a clinical pharmacist (CPst), methodological aspects, as well as definition of his/her role and place $\mathrm{HC}$ areas are important and necessary for the successful implementation of this process. At the same time, the outlined range of problems makes it possible to continue research in this area with a shift in focus to other areas of the CPst activity and his/her promising place in the healthcare system of Ukraine, which is being reformed $[2,3,4]$. Over time, the $\mathrm{CP}$ vector has changed from medicines to a particular patient, it is focused on the needs of the patient in relation to drugs, ways of their administration, drug interactions, rationalization of pharmacotherapy (PT) by management of drug-related problems (DRPs) and pharmaceutical care (PC) $[1,6]$.

The aim of the work was to compare the existing directions and identify the promising areas of the professional activity of CPst taking into account stages of the CP development.

\section{Materials and Methods}

The study object was the professional activity of CPst. Such methods as system analysis, analytical and comparative, forecasting and modeling were used.

\section{Results and Discussion}

According to the results of our study 3 main blocks of the CPst professional activity at the present stage of the CP development in Ukraine have been identified: I) information and terminology; II) methodological-didactic; III) expert and formulary. Further for each of the given blocks we identified, in our opinion, the most ur-

T.B.Ryvak - Candidate of Pharmacy (PhD), associate professor, of the Department of Clinical Pharmacy, Pharmacotherapy and Medical Standardization of the Danylo Halytsky Lviv National Medical University

gent priority areas $(n=15)$. Then we classified the following as the Ist block ( $n=5): 1)$ the evidence search and special evaluation of the clinical and pharmaceutical information; 2) formation of evidential essays as to the clinical requests obtained from doctors; 3 ) the CPst participation in the work of Drug Information Centres; 4) creation and distribution of clinical and pharmaceutical communications; 5) development of the terminology and conceptual apparatus (bibliosemantic study, interpretation of definitions, processing of glossaries) at all stages of the modern development of CP.

The methodological-didactic block provides for $(\mathrm{n}=4)$ : 1 ) development of individual PC models aimed at the medical staff and patients; 2) application of DRP management technologies and determination of the level of drug adherence; 3) conducting workshops, trainings, 5-minute speeches for professionals involved in the drug process; 4) development of the CPst electronic portfolio ( $e$-database; $e$-catalogues, email-newsletter). 


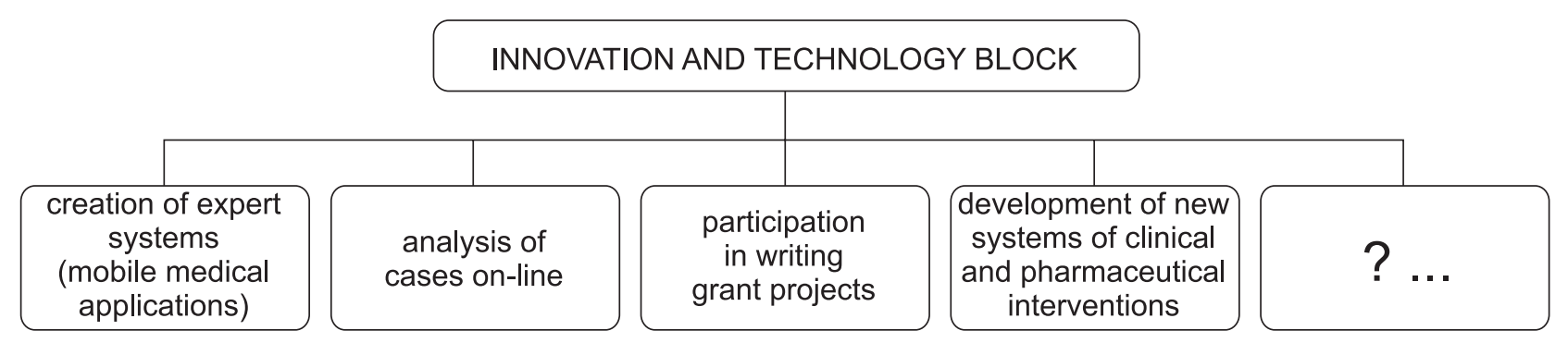

Fig. 1. The promising areas of the CPst professional activity

In particular, the "Information and Retrieval Evidence Base of CPst" database is being developed at the Department of Clinical Pharmacy, Pharmacotherapy and Medical Standardization.

We classified the following as the expert and formulary block $(n=6): 1)$ technical support and revision of the National Formulary (participation in improvement of individual appendices and formulary articles for drugs); 2) management of the formulary drug lists; 3 ) participation in the system of pharmacovigilance (monitoring of adverse reactions of drugs in healthcare institutions, minimization of the risks of PT complications); 4) the expert assessment of PT by medical records; 5) the work of CPst as part of PT committees in healthcare institutions; 6) participation in clinical trials of drugs.

Taking into account the current challenges and the rapid development of innovation technologies the CPst should daily improve his/her knowledge and skills in accordance with vectors of further development of CP. In this regard, 4 priority, in our opinion, and promising areas of the CPst professional activity (Fig. 1) were predicted: creation of expert systems (mobile medical applications); analysis of cases on-line; participation in writing grant projects; search and development of new classification systems of clinical and pharmaceutical interventions integrated into the $4^{\text {th }}$ block - innovation and technology.

It should be noted that the CPst professional activity is not limited to the aforementioned pro- mising areas and can involve a range of many other directions, such as participation in the clinical audit, PT monitoring, pharmacogenetic testing, etc., depending on the specific character of the CP development and features of the healthcare system in Ukraine and in accordance with the passport of CPst specialty.

The CP modern development has led to computerization of many processes. However, in Ukraine this area of CP has not been almost worked out, it is necessary to develop and implement electronic expert systems (medical mobile apps), in particular in Ukrainian, and those that are adapted to the realities of the modern domestic clinical practice. In view of the above, development of such applications based on the popular operating systems for mobile devices (Symbian, Windows Mobile, Android, iPhone, iOS); medical services (mHealth-industry) designed to work with medical data (collection and analysis of medical records about the health status of the patient, in order to facilitate clinical decision-making) is considered to be a promising area of the CPst activity. Similar electronic systems of prescriptions and automated dose delivery systems, electronic monitoring of drug use, etc., have already been created abroad. Among the most famous free mobile apps that simplify and facilitate the daily professional activities of the CPst are: EBM Calculator, Drug Interaction, Pharmacology, Drug Guide, Medical \& Drug Dictionary, Medscape, Medication Guide, Normal Lab Values, MedCalc
3000 Complete, Cardio Drug Interaction, etc.

There are also free mobile apps for patients to manage their own health, which allow monitoring certain indicators at home in case of chronic diseases (monitoring of the blood pressure, heart rate, or a device for measuring blood sugar levels, arrhythmia, etc.), as well as programs that help to increase adherence of patients to their own PT (reminder of the time to take a medicine, especially if they are more than one, indicating the dose, administration regimen concerning meals (before, after or during meals) and comments about the possible interactions and side effects, what to do in case of missing a dose, and if necessary, contact (mobile phone, e-mail) with the doctor, etc.)): Glucose Calculator, CV Risk Calculator, BMI Calculator, SPAC Drug Adherence, Adherence Project, Dose cast - Medication Reminder, myHealth, Medicine Assistant, MediSafe Meds \& Pill Reminder, etc.

The intensive development of new educational technologies in medicine and pharmacy requires some changes in professionallyoriented approaches to the CPst activity. At the stage of the CP implementation into the practical health-care the CPst assessed the PT using only a retrospective analysis of drug administration records. However, this method made it impossible to carry out the actual intervention in the PT process, direct communication with the patient and prevention of DRP. Taking into account the abovementioned we consider it relevant 
New post on Med Ed 101

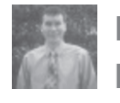

Nitrofurantoin Lung - Drug Induced

Pulmonary Toxicity by Eric Christianson

\begin{abstract}
A 73 year old female has a history of GERD, MI, chronic UTI's, and osteoarthritis. She presents with cough and increasing difficulty catching her breath. She is questioning her provider as to what is going on? Her current medications which have been consistent for over a year: omeprazole aspirin metoprolol nitrofurantoin acetaminophen She reported that $[\ldots]$

$\underline{\text { Read more of this post }}$
\end{abstract}

Eric Christianson | October 7, 2015 at 4:16 pm | Categories: Uncategorized | URL: http://wp.me/p4IcVw-1NW

\title{
Comment
}

See all comments

Fig. 2. An example of the case received to e-mail

to conduct prospective studies in order to assess the PT scheme of a specific patient during inpatient or outpatient treatment. In this perspective, in our opinion, the on-line analysis of cases by individual statements of doctors (Fig. 2) is one of the promising areas, which will provide the professional advice, prevent the DRP development and carry out pharmaceutical intervention at the stage of the PT. We believe that this approach will correspond to the modern patient-oriented concept of the CP.

At the same time, the cases analysed can be a great learning material for continuing professional development of the CPst at the undergraduate and postgraduate levels.

The next area of the CPst professional activity, in our opinion, may be involvement of this specialist in writing grant projects for integration of the international ex- perience to the domestic CP. In particular, in 2014 the EU launched a programme of research and innovation - Horizon 2020, which will last until 2020. The project provides for scientific cooperation in order to search for new and promising areas of research through the support of Future and Emerging Technologies [5].

Today, the key CPst tool to evaluate PT is PCNE methodology to identify DRP. At the same time, the search for new less labour-intensive classification systems as to the CPst pharmaceutical interventions compared to different PCNE versions continues. In particular, the Swiss scientists have developed the GSASA V2 classification system, which is easier to deal with and more promising in terms of documentation for pharmaceutical interventions in daily practice of the CPst, and contains 5 categories and 41 subcategories [7].
Improvement of the system of identifying DRP that are inherent to the national clinical practice at different stages of its development, in our opinion, is one of the priority and promising areas of the CPst professional activity in Ukraine. Separately, it should be noted that summarizing all the above, today all areas of the CPst activity can be narrowed down to a new two-vector concept - DRP management (identification, analysis, standardization, clinical and pharmaceutical intervention, pharmacoeconomic studies, etc.), DRP and formation of the corresponding PC messages (including assessment of its quality). All other areas are either arising out of the above or related to them.

\section{CONCLUSIONS}

1. According to the results of the study conducted three blocks (15 directions) of the modern professional activity and one block (4 directions) of the promising professional activity of a clinical pharmacist in Ukraine have been identified. At the same time, we consider that according to the vectors of further development of clinical pharmacy the professional directions of the clinical pharmacist may vary, but the focus on a patient will be basic and unchanged.

2. Thus, our long-term vision of clinical pharmacy is to build an interdisciplinary team of all professionals related to the process of pharmacotherapy with the support of an effective patient-oriented tailored strategy, modern innovative technologies and to provide consistently high standards of pharmaceutical care.

\section{REFERENCES}

1. Зіменковський А.Б., Ривак Т.Б., Ханик Н.Л. // Клінічна фармація, фармакотерапія та медична стандартизація. - 2011. - №1-2. - С. 23-31.

2. Зіменковський А.Б., Лопатинська О.І., Грем О.Ю. та ін. // Клінічна фармація, фармакотерапія та медична стандартизація. - 2010. - №1-2. - С. 24-34. 
3. Настюха Ю.С. Організаційно-методичні засади створення та діяльності клініко-фармацевтичної служби у стаціонарних закладах охорони здоров'я України: Авторефб. дис. ... канд. фарм. наук: спец. 15.00.01 «Технологія ліків, організація фармацевтичної справи та судова фармація» / Ю.С.Настюха. - Л., 2013. - 26 с.

4. Ривак Т.Б. Клініко-фармацевтична складова концептуальної моделі раціональної фармакотерапії в охороні здоров'я України: Автореф. дис. ... канд. фарм. наук: спец. 15.00 .01 «Технологія ліків, організація фармацевтичної справи та судова фармація» / Т.Б.Ривак. - Л., 2012. - 22 с.

5. HORIZON 2020. The EU Framework Programme for Research and Innovation http://ec.europa.eu/ programmes/horizon2020/

6. Lampert L. Markus. Application and Evaluation of an Instrument for the Documentation of Clinical Pharmaceutical Interventions // Postgraduate Education in Hospital Pharmacy FPH. Diploma Thesis. - Basel, 2007. - P. 42.

7. Maes K.A., Tremp R.M., Hersberger K.E. // Intern. J. of Clin. Pharmacy. - 2015. - №37 (6). - P. 1-10.

\title{
ПРІОРИТЕТНІ СУЧАСНІ ТА ПЕРСПЕКТИВНІ НАПРЯМКИ ФАХОВОЇ ДІЯЛЬНОСТІ КЛІНІЧНОГО ПРОВІЗОРА НА РІЗНИХ ЕТАПАХ РОЗВИТКУ КЛІНІЧНОЇ ФАРМАЦІЇ В УКРАЇНІ
}

\author{
Т.Б.Ривак, А.Б.Зіменковський, Х.І.Макух
}

Львівський національний медччний університет ім. Данила Галицького

Ключові слова: клінічна фармація; фармацевтична опіка; фахова діяльність клінічного провізора

\begin{abstract}
В Україні клінічна фармація перебуває на етапі інтенсивного розвитку, їі ключові положення поступово впроваджуються у практичну охорону здоров'я. Важливими та необхідними для успішної реалізації цього процесу є нормативне та правове забезпечення діяльності клінічного провізора, методологічні аспекти, а також визначення його ролі та місця у різних напрямках охорони здоров'я. Нами проведено порівняльне дослідження існуючих та перспективних напрямків фахової діяльності клінічного провізора з урахуванням етапів розвитку клінічної фармації. За результатами проведеного дослідження визначено 3 основні блоки (15 напрямків) фахової діяльності клінічного провізора на сучасному етапі розвитку клінічної фармації в Україні: I) інформаційнотермінологічний; II) методологічно-дидактичний; III) експертно-формулярний. Також ми виокремили 1 блок (4 напрямки) перспективної фахової діяльності клінічного провізора в Україні, а саме: створення експертних систем (мобільних медичних додатків); розбір «сазе»-випадків в оп-linе режимі; участь у написанні грантових проектів; пошук і розробка нових класифікаційних систем клініко-фармацевтичних втручань. Окремо зазначимо, узагальнюючи все вищенаведене, що сьогодні всі напрямки діяльності клінічного провізора можна звести до нової, на наш погляд, двовекторної концепції - менеджмент ліко-пов'язаних проблем (виявлення, аналіз, стандартизація, клініко-фармацевтичні втручання, фармакоекономічні дослідження тощо) та формування відповідних меседжів фармацевтичної опіки (включно з оцінкою їі якості). Разом із тим ми вважаємо, що відповідно до векторів подальшого розвитку клінічної фармації професійні напрямки клінічного провізора можуть змінюватися.
\end{abstract}

\section{ПРИОРИТЕТНЫЕ СОВРЕМЕННЫЕ И ПЕРСПЕКТИВНЫЕ НАПРАВЛЕНИЯ ПРОФЕССИОНАЛЬНОЙ ДЕЯТЕЛЬНОСТИ КЛИНИЧЕСКОГО ПРОВИЗОРА НА РАЗНЫХ ЭТАПАХ РАЗВИТИЯ КЛИНИЧЕСКОЙ ФАРМАЦИИ В УКРАИНЕ}

\section{Т.Б.Рывак, А.Б.Зименковский, Х.И.Макух}

Львовский национальный медицинский университет им. Данила Галицкого

Ключевые слова: клиническая фармация; фармацевтическая опека; профессиональная деятельность клинического провизора

В Украине клиническая фармация находится на этапе интенсивного развития, ее ключевые положения постепенно внедряются в практическое здравоохранение. Важными и необходимыми для успешной реализации этого процесса является нормативное и правовое обеспечение деятельности клинического провизора, методологические аспекты, а также определения его роли и места в разных направлениях здравоохранения. Проведено сравнительное исследование существующих и перспективных направлений профессиональной деятельности клинического провизора с учетом этапов развития клинической фармации. По результатам проведенного исследования определены 3 основных блока (15 направлений) профессиональной деятельности клинического провизора на современном этапе развития клинической фармации в Украине: I) информационно-терминологический; II) методологично-дидактический, III) экспертно-формулярный. Также мы выделили 1 блок (4 направления) перспективной профессиональной деятельности клинического провизора в Украине, а именно: создание экспертных систем (мобильных медицинских приложений); разбор «саsе»-случаев в оn-line режиме; участие в 
написании грантовых проектов; поиск и разработка новых классификационных систем клинико-фармацевтических вмешательств. Отдельно отметим, обобщая все вышесказанное, что сегодня все направления деятельности клинического провизора можно свести к новой, на наш взгляд, двухвекторной концепции - менеджмент проблем, связанных с лекарствами (выявление, анализ, стандартизация, клинико-фармацевтические вмешательства, фармакоэкономические исследования и т. п.) и формирование соответствующих меседжей фармацевтической опеки (включая оценку ее качества). Вместе с тем мы считаем, что в соответствии с векторами дальнейшего развития клинической фармации профессиональные направления клинического провизора могут изменяться.

Address for correspondence:

Received in 06.04.2016

11, Mykolaychuk str., Lviv, 79059.

Tel. (322) 58-74-10. E-mail: tanita05@yandex.ua.

Danylo Halytsky Lviv National Medical University 